\title{
CpG Island Methylation of TMS1/ASC and CASP8 Genes in Cervical CANCER
}

\author{
D. M. Kordi Tamandani1,2, R. C. Sobti ${ }^{1}$, M. Shekari1 ${ }^{1,3}$, A. Huria ${ }^{4}$ \\ ${ }^{1}$ Department of Biotechnology, Panjab University, Chandigrah, India, \\ ${ }^{2}$ Department of Biology, Sistan and Baluchistan University, Zahedan, Iran, \\ ${ }^{3}$ Department of Genetic, Hormozgan University of Medical Sciences ,Bandarabbas, Iran \\ ${ }^{4}$ Department of Obstetrics and Gynaecology, Government Medical College and Hospital, Chandigrah, India
}

\begin{abstract}
Background: Gene silencing associated with aberrant methylation of promoter region $\mathrm{CpG}$ islands is an acquired epigenetic alteration that serves as an alternative to genetic defects in the inactivation of tumor suppressor and other genes in human cancers.

Aims: This study describes the methylation status of TMS1/ASC and CASP8 genes in cervical cancer. We also examined the prevalence of TMS1/ASC and CASP8 genes methylation in cervical cancer tissue and none - neo plastic samples in an effort to correlate with smoking habit and clinicopathological features. Method: Target DNA was modified by sodium bisulfite, converting all unmethylated, but not methylated, cytosines to uracil, and subsequently amplified by Methylation Specific (MS) PCR with primers specific for methylated versus unmethylated DNA. The PCR product was detected by gel electrophoresis and combined with the clinical records of patients.

Results: The methylation pattern of the TMS1/ASC and CASP8 genes in specimens of cervical cancer and adjacent normal tissues were detected [5/80 (6.2\%), $3 / 80(3.75 \%)-2 / 80(2.5 \%), 1 / 80(1.2 \%)$ respectively]. No statistical differences were seen in the extent of differentiation, invasion, pathological type and smoking habit between the methylated and unmethylated tissues $(P>0.05)$.

Conclusion: The present study conclude that the frequency of TMS1/ASC and CASP8 genes methylation in cervical cancer are rare $(<6 \%)$, and have no any critical role in development of cervical cancer.
\end{abstract}

Key words: Methylation, TMS1/ASC, CASP8, cervical cancer

\section{INTRODUCTION}

Cervical cancer is the second most common cancer and an important cause of death in women worldwide [1]. Therefore, it is likely that host genetic and epigenetic events play an important role in cervical carcinogenesis .The term "epigenetic"is used to describe mitotically and meiotically heritable states of gene expression that are not due to changes in DNA sequence [2]. DNA methylation is an epigenetic mechanism used for long-term silencing of gene expression. The methylation pattern is established during development and is normally maintained throughout the life of an individual. It has been shown that such epigenetic mecha- nisms can be important in initiating tumorogenesis and supporting the malignant state of cancer cells [3].

Apoptosis is mediated by a family of cystine proteases called caspases. CASP 8 , located at chromosome 2q33-34, encodes caspase 8, an initiator caspase that plays an important role in the Fas- ligand pathway [4]. Alterations of these genes have been described in several neoplasias, such as mutations in colon cancer and promoter hypermethylation in medulloblastomas and neuroblastomas [5]. TMS1 gene located on 16p11.2-12 chromosome has function such as activates pro caspas1-8, modulates NF-KappaB activation pathway [6]. TMS1/ASC is a bipartite protein comprising two protein-protein interaction domains, a pyrin domain (PYD) and a caspase recruitment domain (CARD). Proteins containing these domains play crucial roles in regulating apoptosis and immune response pathways, and mutations in a number of PYD- and CARDcontaining proteins have been linked to auto-inflammatory diseases and cancer [7]. This gene is also known as ASC (Apoptosis Speck like protein containing a CARD) [8]. So, the down regulation of TMS1/ASC in breast cancer cell lines correlates with dense methylation on the $\mathrm{CpG}$ islands [9]. Methylation of the promoter region of TMS1/ASC has also been identified in small cell lung cancer and non-small cell lung cancer [10], human glioblastoma [11], ovarian tumors [12], colorectal cancer [13], neuroblastoma [14], and melanoma [15]. It was appeared no correlation between methylation of the TMS1/ASC gene and acute lymphoblastic leukemia [16]. Tischoff et al. [17] reported that promoter methylation of the proapoptotic genes CASP8 and TMS1 are involved in the malignant epithelial liver tumor. The role of epigenetic (gene inactivation) in tumorigenesis in gynecologic malignancies have been poorly understood. So, we investigated the promoter methylation status in CASP8 and TMS1 genes and relationships between clinopathologic parameters and methylation status with risk of cervical cancer.

\section{MATERIALS AND METHODS}

\section{STUDY SubJECTS}

The case -control study involved collection of tissue samples of 160 North Indian subjects. 80 cases were newly diagnosed, previously untreated and histologically confirmed as cervix cancer patients. The samples were collected from the Post graduate Institute of Medical Education and Research (PGIMER) Chandi- 
garh and Government Medical College (GMC), Chandigarh. The control tissue samples $(n=80)$ were collected from the same institute with no history of cancer or pre cancer. Informed consent was obtained from all the cases and controls.

\section{DNA EXTRACTION}

Genomic DNA was isolated from tissue samples by the procedure of Roe et al. [18]. For the DNA methylation studies, $1 \mu \mathrm{g}$ of genomic DNA was processed and modified with sodium bisulfite using the Intergen CpGenome DNA modification kit (Intergen, Norcross, GA). Briefly, genomic DNA was modified by sodium bisulfite, desulfonated with sodium hydroxide, and then purified and resuspended in TE $(10 \mathrm{mM}$ Tris, $0.1 \mathrm{mM}$ EDTA, pH 7.5). Negative control (no sample) and positive control (in vitro methylated and bisulfite treated human placenta DNA) were included in all reaction . The methylation-specific (MS) PCR conditions and the sequences of premiers are used for TMS1/ ASC and Caspes- 8 previously described by Liu et al. [19] and Lázcoz et al . [20] respectively .

The positions of the $191 \mathrm{bp}$ PCR product representing the methylated and unmethylated $196 \mathrm{bp}$ alleles for TMS1/ASC were separated on 3\% agarose gels (Fig.1). In case of Caspes-8, the PCR products for the methylated and unmethylated alleles which separated on 3\% were 321 and 320 bp respectively (Fig.2).

\section{StATISTICAL ANALYSis}

The results combined with the clinical records of $\mathrm{Pa}$ tients were analyzed with the the Epi-Info software (Epi-Info, version 3.2, Centers for Disease Control and prevention, Atlanta, GA, USA) and the software package SPSS, version 10.0 (SPSS, Chicago, IL, USA). Significance was set at $P \leq 0.05$.

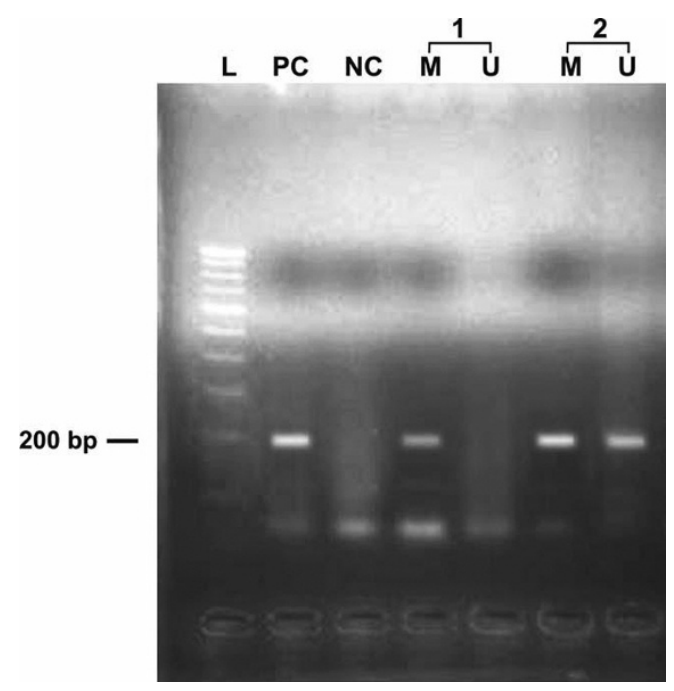

Fig. 1. Methylation analysis of TMS1/ASC in cervical cancer. Lane U: amplified product with primers recognizing unmethylated sequence; Lane M: amplified product with primers recognizing methylated sequence. NC, normal control; PC, positive control for methylation. L: ladder (100bp).

\section{RESULTS}

The methylation status of the TMS1/ASCand Caspase8 in primary cervical cancer and control non-neoplastic cervix tissue specimens derived from north India population was analyzed.

There were no methylation frequency association for TMS1/ASC gene with various clincopathological parameters including: age, smoking, histological type, and stage $(P>0.05)$ (Table 1$)$. Similarly, same result was observed for Caspase- 8 gene with various clinicopathological parameters (Table.2).

The status of promoter methylation for TMS1/ ASCand Caspase- 8 genes in 80 primary cervical cancer tissue and 80 control non-neoplastic cervix tissue specimens were examined. The promoter methylation frequency for TMS1/ASC gene in cervical cancer and control were $6.2 \%(5 / 80), 3.75 \%(3 / 80)$ respectively.

The methylation status of the Caspase- 8 gene was detected in cervical cancer tissue 2.5\% (2/80) and normal tissue $1 / 80(1.2 \%)$. There was no deference significant methylation frequency for the TMS1/ASC and Caspase- 8 genes as compared to controls non-neoplastic cervix.

\section{Discussion}

The effect of DNA hypermethylation in gene promoter regions is similar to genetic loss-offunction mutations [21]. Many cellular pathways are inactivated by this epigenetic event, including DNA repair, cell cycle, apoptosis, cell adherence, and detoxification [22]. The specific patterns of $\mathrm{CpG}$ island hypermethylation between tumor types may provide a useful signature for tumor diagnosis and prognosis [23]. TMS1/ASC gene was originally identified as a target of methylation-induced silencing using cell lines that over express DNA

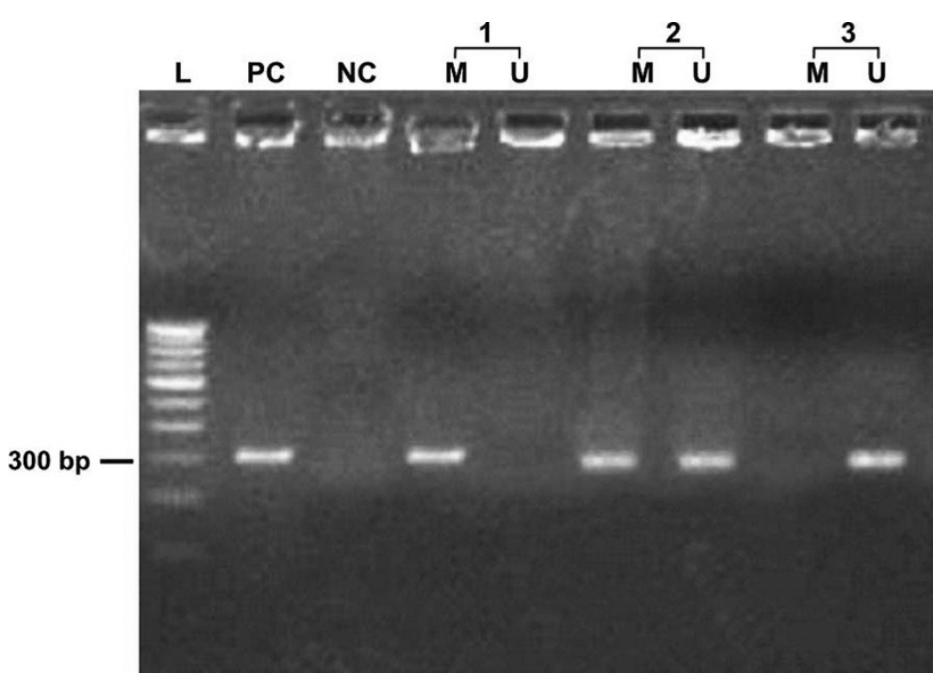

Fig. 2. Methylation analysis CASP8 in cervical cancer. Lane U: amplified product with primers recognizing unmethylated sequence; Lane M: amplified product with primers recognizing methylated sequence. $\mathrm{NC}$, normal control; PC, positive control for methylation. L: ladder (100bp). 
Table1. The relationship between TMS1 promoter methylation and clinicopathology parameter of cervical cancer.

\begin{tabular}{|c|c|c|c|c|}
\hline Characteristic & overall & present & Absent & $P$ Value \\
\hline$<50$ & 44 & $2(4.5 \%)$ & $42(95.4 \%)$ & \multirow[b]{2}{*}{0.65} \\
\hline$>50$ & 36 & $3(8.3 \%)$ & $33(91.6 \%)$ & \\
\hline Smoker & 5 & $1(20 \%)$ & $4(80 \%)$ & \multirow{2}{*}{0.28} \\
\hline Nonsmoker & 75 & $4(5.3 \%)$ & $71(94.6 \%)$ & \\
\hline \multicolumn{5}{|l|}{ Histological type } \\
\hline $\mathrm{SCC}$ & 68 & $4(5.8 \%)$ & $64(94.1 \%)$ & \multirow[t]{2}{*}{0.56} \\
\hline $\mathrm{AC}$ & 12 & $1(8.3 \%)$ & $11(91.6 \%)$ & \\
\hline \multicolumn{5}{|l|}{ Stage } \\
\hline $\mathrm{Ib}$ & 46 & $1(2.2 \%)$ & $45(97.8 \%)$ & \multirow{4}{*}{0.10} \\
\hline IIa & 12 & $2(16.6 \%) \mathrm{IIb}$ & $10(83.3 \%)$ & \\
\hline $\mathrm{IIb}$ & 19 & $2(10.5 \%)$ & $17(89.4 \%)$ & \\
\hline $\mathrm{IIIb}$ & 3 & - & $3(100 \%)$ & \\
\hline
\end{tabular}

Table 2. The relationship between Caspase-8 promoter methylation and clinicopathology parameter of cervical cancer.

\begin{tabular}{lllll}
\hline Characteristic & overall & present & Absent & P Value \\
\hline$<50$ & 44 & 0 & $44(100 \%)$ & - \\
$>50$ & 36 & $2(5.6 \%)$ & $34(94.4 \%)$ & \\
Smoker & 5 & $1(20 \%)$ & $4(80 \%)$ & 0.12 \\
Nonsmoker & 75 & $1(1.3 \%)$ & $74(98.6 \%)$ & \\
Histological type & & & & \\
SCC & 68 & $2(2.9 \%)$ & $66(97.05 \%)$ & \\
AC & 12 & - & & \\
& & & & \\
Stage & 46 & $1(2.17 \%)$ & $45(97.8 \%)$ & 0.37 \\
Ib & 12 & $1(8.3 \%)$ & $11(91.6 \%)$ & \\
II & 19 & - & - & \\
IIb & 3 & - & - & \\
IIIb & & &
\end{tabular}

methyltransferase 1 (DNMT1). In another critical pathway mediating cell death via death receptors, CASP8 acts as a key apoptotic enzyme by serving as an "initiator CASP"; moreover, CASP8 was recently shown to be silenced by aberrant methylation [24]. However, because the 5' region of CASP8 does not contain a typical $\mathrm{CpG}$ island, the relevance of methylation to its silencing remains unclear [25]. TMS1/ASC is a novel proapoptotic gene previously identified as a target of DNA methylation in breast cancer [26]. Terasawa et al. [27] showed that aberrant methylation of the $5^{\prime}$ region of TMS1/ASC is well correlated with loss of expression in ovarian cancer. Notably, decreasing TMS1/ASC expression reduces sensitivity to chemotherapeutic drugs [28]. The methylationmediated silencing of TMS1/ASC would be expected to contribute to a survival advantage for tumor cells, by enabling them to escape apoptosis, which supports a role for aberrant methylation in human ovarian tumorigenesis [29]. Approximately 40\% (10/17) of primary breast tumors also exhibited aberrant methylation of the TMS1/ASC gene. Different studies have confirmed the frequency of aberrant methylation of TMS1/ASC in primary breast cancers, ranging from $10 \%$ to $40 \%$. Methylation-associated silencing of the TMS1/ ASC gene was observed in 11\% of gastric carcinomas, $40 \%-41 \%$ of small cell and non small cell lung carcinomas, $50 \%$ of malignant melanomas, and $44 \%$ of primary glioblastomas [30, 31]. Jens et al. [32] reported frequency of methylation for Caspase- 8 $(1.2 \%)$ and TMS1 (5.1\%) in ovarian cancer, and concluded that, methylation of these genes in regulation of apoptosis was no significant $(P=0.74)$. In line of our study Feng et al. [33] demonstrated the rate of hypermethylation for TMS1 to be $3.1 \%$ in controls and $6.7 \%$ in patient with cervical cancer. Liu et al. [34] found that aberrant methylation of the TMS1 gene was detected in tumor tissues $\% 36.1$ with Choangio carcinoma, and in normal tissue $8.3 \%$. So, there were no statistical differences in age, gender, pathologic type between the methylated and unmethylated tissues. Aberrant methylation of TMS1 gene was detected in 15 of 80 ovarian cancer tissue $(19 \%)$ but in none of the normal ovary specimens [35]. Michalowski et al. 
[36] observed, hypermethylation of Caspase- 8 in 38\% in neuroblastoma. Matinez et al. [37] strongly suggested that hypermethylation of the pro-apoptotic Caspase8 in glioblastoma $(P=0.0035)$. The present study's results were consonance with those of Yang et al. [38] who carried out a similar study in Chinas women. However, our study has several potential limitations. First, we were not able to incorporate into the model information concerning the relative level of hypermethylation of each specific gene. It is possible that other gene combinations, which may have increased sensitivity and specificity, will be identified through the use of real-time PCRbased assays such as MethyLight [39], which provided information on the relative level of hypermethylation of each specific gene examined. Second, we limited our search for useful hypermethylated genes to an assessment of 2 genes that had been previously reported to be associated with cancers at other sites. Identification of additional novel CpG islands that are specifically associated with cervical cancer will be needed to construct a panel with higher sensitivity that maintains high specificity, and studies examining detection of such a panel of genes using recently developed quantitative assays should be undertaken. More study using a much larger samples size are needed to further define the potential role of methylated DNA marker in cervical cancer management.

Acknowledgments: The authors are grateful to University Grant Commission (UGC) -New Delhi, India, and University of Sistan and Baluchistan - Zahedan, Iran, for supporting this project financially.

\section{REFERENCE}

1. Jemal A, Murray T, Samuels A, Ghafoor A, Ward E, Thun MJ. 2003 Cancer statistics. CA Cancer J. Clin 53, 526.

2. Adcock IM, Ford P, Barnes PJ, Ito K. 2006.Epigenetics and airways disease. Respir Res. 6, 21

3. Chen, W. et al. 2004.Epigenetic and genetic loss of Hic1 function accentuates the role of $\mathrm{p} 53$ in tumorigenesis. Cancer Cell. 6, 387-398 .

4. Wolf BB, Green DR. 1999.Suicidal tendencies: apoptotic cell death by caspase family proteinases.J Biol Chem. 274,20049-20052

5. Gonzalez-Gomez P, Bello MJ, Inda MM, Alonso ME, Arjona D, Aminoso C, Lopez-Marin I, de Campos JM, Sarasa JL, Castresana JS, Rey JA: 2004.Deletion and aberrant $\mathrm{CPG}$ island methylation of Caspase 8 gene in medulloblastoma.Oncol Rep.12,663-666.

6. Philchenkov A, Zavelevich M, Tadeusz J. Kroczak. 2004. Caspases and cancer: mechanisms of inactivation and new treatment modalities.Exp Oncol. 26,82-97.

7. McConnell BB, Vertino PM. 2000. Activation of a caspase-9-mediated apoptotic pathway by subcellular redistribution of the novel caspase recruitment domain protein TMS1. Cancer Res.60,6243-7.

8. McConnell BB, Vertino PM. 2004. TMS1/ASC: the cancer connection. Apoptosis.9,5-18.

9. Grenier JM, Wang L, Manji GA, Huang WJ, Al-Garawi A, Kelly R, Carlson A, Merriam S, Lora JM, Briskin M, DiStefano PS, Bertin J. 2002.Functional screening of five PYPAF family members identifies PYPAF5 as a novel regulator of NF-kappaB and caspase-1. FEBS Lett.530, 73-78.
10. Virmani A, Rathi A, Sugio K, Sathyanarayana UG, Toyooka S, Kischel FC, Tonk V, Padar A, Takahashi T, Roth JA, Euhus DM, Minna JD, Gazdar AF. 2003. Aberrant methylation of TMS1 in small cell, non small cell lung cancer and breast cancer. Int J Cancer. 106,198-204

11. Stone AR, Bobo W, Brat DJ, Devi NS, Van Meir EG, Vertino PM. 2004. Aberrant methylation and down-regulation of TMS1/ASC in human glioblastoma. Am J Pathol. 165,1151-1161.

12. Dhillon VS, Aslam M, Husain SA. 2004.The contribution of genetic and epigenetic changes in granulosa cell tumors of ovarian origin. Clin Cancer Res.10,5537-5545.

13. Yokoyama T, Sagara J, Guan X, Masumoto J, Takeoka M, Komiyama Y, Miyata K, Higuchi K, Taniguchi S. 2003. Methylation of $A S C / T M S 1$, a proapoptotic gene responsible for activating procaspase-1, in human colorectal cancer. Cancer Lett.202,101-108.

14. Alaminos M, Davalos V, Cheung NK, Gerald WL, Esteller M. 2004.Clustering of gene hypermethylation associated with clinical risk groups in neuroblastoma. J Natl Cancer Inst. 96,1208-1219.

15. Guan X, Sagara J, Yokoyama T, Koganehira Y, Oguchi M, Saida T, Taniguchi S. 2003. ASC/TMS1, a caspase-1 activating adaptor, is downregulated by aberrant methylation in human melanoma. Int J Cancer. 107,202-208.

16. Roman-Gomez J, Jimenez-Velasco A, Castillejo JA, Agirre X, Barrios M, Navarro G, Molina FJ, Calasanz MJ, Prosper F, Heiniger A, Torres A. 2004. Promoter hypermethylation of cancer-related genes: a strong independent prognostic factor in acute lymphoblastic leukemia. Blood.104,2492-2498.

17. Tischoff, H Witzgmann, J Hauss C Wittekind, A Tannapfel . 2006.CpG island methylation of proapoptotic genes in hepatocellular carcinoma and cholangiocarcinoma. Z Gastroenterol.44 DOI: 10.1055/s-2006-931705.

18. Roe BA, Crabtree JS, Khan AS. 1995. Methods for DNA isolation.Part III. In: Protocols for recombinant DNA isolation, cloning, and sequencing [Internet edition]. Norman, OK: University of Oklahoma;. Available from: http://www.genome.ou.edu/protocol_book/protocol_in dex.html; also available in paper copy as: DNA isolation and sequencing; New York: Wiley; 1996

19. Liu X, Zhu S, Zhang H, Xu H, Su H,Li S and Zhou X. 2006. The methylation status of the TMS1/ASC gene in cholangiocarcinoma and its clinical significance. Hepatobiliary Pancreat Dis Int.5, 449-453.

20. Lázcoz P, Muñoz J, Nistal M, Pestaña A, Encío I, Castresana JS. 2006. Frequent promoter hypermethylation of RASSF1A and CASP8 in neuroblastoma. BMC Cancer. 25;6:254.

21. Jones PA. .2003. Epigenetics in carcinogenesis and cancer prevention. Ann N Y Acad Sci. 983,213-9.

22. Esteller M: 2002. CpG island hypermethylation and tumor suppressor genes: a booming present, a brighter future. Oncogene.21, 5427-5440.

23. Laird PW: 2003. The power and the promise of DNA methylation markers. Nat Rev Cancer. 3,253-266.

24. Teitz T, Wei T, Valentine MB, et al. 2000. Caspase 8 is deleted or silenced preferentially in childhood neuroblastomas with amplification of MYCN. Nat Med.6,529-35.

25. Banelli B, Casciano I, Croce M, et al. 2002. Expression and methylation of CASP8 in neuroblastoma: identification of a promoter region. Nat Med.8.1333-1335.

26. Conway KE, McConnell BB, Bowring CE, et al. 2000.TMS1, a novel proapoptotic caspase recruitment domain protein, is a target of methylation- induced gene silencing in human breast cancers. Cancer Res. 60,6236-42.

27. Terasawa K, Sagae S, Toyota M, Tsukada K, Ogi K, Satoh A, MitaH, et al. 2000. Epigenetic Inactivation of TMS1/ ASC in Ovarian Cancer. Clin Cancer Res. 10,2000-6 
28. Masumoto J, Taniguchi S, Ayukawa K, et al. 1999. ASC, a novel $22-\mathrm{kDa}$ protein, aggregates during apoptosis of human promyelocytic 60 cells. J Biol Chem.274,33835-8.

29. Stimson KM, Vertino PM. 2002. Methylation-mediated silencing of TMS1/ASC is accompanied by histone hypoacetylation and $\mathrm{CpG}$ islandlocalized changes in chromatin architecture. J Biol Chem. 277: 4951-8.

30. Martinez R, Setien F, Voelter C, Casado S, Quesada MP, Schackert G, Esteller M. 2007 .CpG island promoter hypermethylation of the pro-apoptotic gene caspase- 8 is a common hallmark of relapsed glioblastoma multiforme. Carcinogenesis. 28,1264-8.

31. Ohtsuka T, Liu XF, Koga Y, Kitajima Y, Nakafusa Y, Ha $\mathrm{CW}$, et al. 2006. Methylation-induced silencing of $A S C$ and the effect of expressed ASC on p53-mediated chemosensitivity in colorectal cancer. Oncogene.25,18071811.

32. Jens M. Teodoridis, Hall J, Marsh S ,. Kannall H, Smyth C, et al., 2005. CpG Island Methylation of DNA Damage Response Genes in Advanced Ovarian Cancer .Cancer Res. 65, 8961-7.

33. Feng Q, Balasubramanian A, Stephen E. Hawes, Toure P, Sow P, DemA, Dembele B, et al . 2005.Detection of Hypermethylated Genes in Women With and Without Cervical Neoplasia. Journal of the National Cancer Institute. $97,273-82$

34. Liu X, Zhu S, Zhang H, Xu H, Su H,Li S and Zhou X. 2006. The methylation status of the TMS1/ASC gene in cholangiocarcinoma and its clinical significance. Hepatobiliary Pancreat Dis Int.5, 449-453.

35. Terasawa K, Sagae S, Toyota M, Tsukada K, Ogi K, Satoh A, MitaH ,et al . 2000. Epigenetic Inactivation of TMS1/ASC in Ovarian Cancer. Clin Cancer Res. 10,2000-6.
36. Michalowski MB, de Fraipont F, Plantaz D, Michelland S, Combaret V, Favrot MC. 2007. Methylation of tumorsuppressor genes in neuroblastoma: The RASSF1A gene is almost always methylated in primary tumors. Pediatr Blood Cancer. Jun 14; [Epub ahead of print

37. Martinez R, Setien F, Voelter C, Casado S, Quesada MP, Schackert G, Esteller M. 2007 .CpG island promoter hypermethylation of the pro-apoptotic gene caspase- 8 is a common hallmark of relapsed glioblastoma multiforme. Carcinogenesis. 28,1264-8.

38. Yang HJ, Liu VWS, Wang Y, Chan KYK, Tsang PCK, Khoo US, Cheung ANY, Ngan HYS: 2004. Detection of Hypermethylated Genes in Tumour and Plasma of Cervical Cancer Patients. Gynecol Oncol.93,435-40.

39. Eads CA, Danenberg KD, Kawakami K, Saltz LB, Blake C, Shibata D, et al.MethyLight: a highthroughput assay to measure DNA methylation. NucleicAcids Res 2000; 28

Received: February 6, 2008 / Accepted: November 5, 2008

Address for correspondence:

Dor Mohammad Kordi Tamandani,

Department of Biology

Sistan and Baluchistan University

Zahedan

Iran

Tel.: $\quad+98-9151906853$

Fax: +98-541-2416565

E-mail: dor_kordi@yahoo.com 